\title{
EFFECT OF AROMATASE INHIBITOR THERAPY ON PREDICTED ADULT HEIGHT IN PREPUBERTAL BOYS WITH IDIOPATHIC SHORT STATURE
}

\author{
BY \\ Thamar Mahmoud ${ }^{1}$, Hoda A. Salem ${ }^{2}$, Ezz EL-Denshary ${ }^{3}$, Shahira F. El-menshwe ${ }^{4}$, \\ Khaled Salem ${ }^{5}$, Naglaa Assaf ${ }^{6}$. \\ FROM \\ ${ }^{1}$ Department of Clinical Pharmacy, Faculty of Pharmacy, MISR University \\ ${ }^{2}$ Department of Clinical Pharmacy, Faculty of Pharmacy, El-Azhar University \\ ${ }^{3}$ Department of Pharmacology and Toxicology, Faculty of Pharmacy, Cairo University \\ ${ }^{4}$ Department of Pharmaceutics and Industrial Pharmacy, Faculty of Pharmacy, \\ Bani Seuf University \\ ${ }^{5}$ Department of Urology, Faculty of Medicine, Tanta University \\ ${ }^{6}$ Department of Pharmacology and Toxicology, Faculty of Pharmacy, MISR University

\section{Objective}

To investigate the effect of blocking estrogen biosynthesis with anastrozole, a potent aromatase inhibitor (AI) on growth and consequently predicted adult height (PAH) in boys with high estrogen level. Also, the effects of aromatase inhibition on gonadotropin secretion in boys during prepubertal phase.

\section{Study design}

A retrospective, double-blind, randomized, placebo (Pl)-controlled study was done. Forty boys, aged 9.0-14.5 yr, diagnosed with idiopathic short stature (ISS) were enrolled into the study. The children were classified into two groups ( 20 children each). The control group received starch tablet daily for one year. The second group received anastrozole tablet $1 \mathrm{mg}$ orally/day for one year. Laboratory investigations were estimated: serum estradiol $\left(\mathrm{E}_{2}\right)$, testosterone $(\mathrm{T})$, follicle stimulating hormone $(\mathrm{FSH})$, luteinizing hormone (LH), and insulin-like growth factor type 1(IGF1) levels. Height estimation was also included.

\section{Results}

Serum $\mathrm{T}$ levels were significantly increased, while serum $\mathrm{E}_{2}$ levels were significantly decreased after anastrozole treatment. However, the levels of serum LH, 
FSH and IGF1 did not change significantly in anastrozole group. On the other hand, the levels of height were significantly increased in anastrozole group whereas showed no changes occurred in the respective measures in control boys.

\section{Conclusion}

Anastrozole delays bone maturation and improves PAH in boys with ISS.

\section{Keywords}

growth hormone $(\mathrm{GH})$, testosterone $(\mathrm{T})$, estradiol $\left(\mathrm{E}_{2}\right)$, aromatase inhibitor (AI), predicted adult height (PAH), idiopathic short stature (ISS).

\section{Introduction}

Idiopathic short stature (ISS) or non-GH-deficient short stature is a condition of a decreased childhood growth without any cause. These children have a height that is below normal, and others have growth failure similar to that of GH deficiency (Wit et al., 1995; Root et al., 1998). Families of such children seek medical intervention such as GH treatment. So, thousands of children with ISS receive GH therapy (Wilton, 1999; Maneatis et al., 2000).

Estrogen is responsible for the development of secondary sexual characteristics and plays a major role in reproductive function in women. There is a close relationship between estrogen and $\mathrm{GH}$ in the regulation of growth and development in puberty ( Leung et al., 2004) Estrogen promotes GH secretion by stimulating growth hormone release (GRH). This is responsible for the adolescent growth spurt. Estrogen is derived by aromatization of adrenal androgen in both sexes (Divya et al., 2011).

The role of estrogen in the regulation of growth has been identified during the past decade. The action of estrogen involves other hormones and factors such as GH, insulin like growth factors (IGFs) and their binding proteins, thyroid hormone (TH), vitamin D, retinoids, parathyroid hormone (PTH) and PTH-related peptide, cytokines, and their receptors (Stevens and Williams, 1999). Estrogen plays a major role in the pubertal growth spurt, skeletal maturation, and the accrual and maintenance of bone mass in both females and males. Estrogen affects pubertal skeletal growth as it initiates the pubertal growth spurt and stimulates skeletal growth (Juul, 2001)

Testosterone plays a major role in the pubertal growth spurt in boys. Testosterone is the most important androgen of men, and it is secreted by testis. A large amount of weakly active androgens is secreted by adrenal cortex (Hochberg et al., 1985).

Testosterone is important for differentiation of male gonadal structures before birth. In adulthood, it is important for sexual maturation during puberty and for maintenance of male secondary sexual characteristics, genital function and spermatogenesis. Testosterone is also has a major role on bone mass accrual. Men have 
a larger skeletons and greater muscle mass than women. So, they have high androgen levels (Vanderschueren et al., 2004).

Aromatase inhibitors are classified as either steroidal or nonsteroidal, or as first, second or third generation. Steroidal inhibitors such as formestane and exemestane inhibit aromatase activity by mimicking the substrate androstenedione. The thirdgeneration nonsteroidal enzyme inhibitors such as anastrozole and letrozole inhibit enzyme activity by binding with the heme iron of the enzyme (active site of P450 aromatase) through interaction of heterocyclic nitrogen that is critical for their markedly increased activity (Wit et al., 2011). AIs have been reported to treat some disorders such as estrogen-responsive breast cancer, endometriosis, peripheral precocious puberty, congenital adrenal hyperplasia $(\mathrm{CAH})$, short stature, and gynecomastiain children and adolescents (Dunkel, 2006). Also AIs are used to decrease estrogen and increase androgen levels so, it may extend the period of growth in prepubertal period (Wiren et al, 1999).

The mechanism of action of AIs to improve the final adult height is suppressing estrogen formation after the onset of puberty. The result is delaying the closure of the epiphyses, and allowing for a long period of growth The reported adverse effects of AIs, are reduced bone mineral density (BMD), metabolic effects including a propensity for insulin resistance and dyslipidemia, and impairment of the hypothalamic-pituitarygonadal axis (Mauras et al., 2000).

Therefore, the current study was aimed to investigate the effect of blocking estrogen biosynthesis with an aromatase inhibitor on growth and consequently predicted adult height in boys with high estrogen level. Secondarily, the effects of aromatase inhibition on gonadotropin secretion in boys during prepubertal phase.

\section{Patients and Methods}

\section{Patients}

The study was carried on 40 boys with high estrogen level aged from nine to fourteen years who attended at the outpatients Clinic of urology, Tanta University Hospital.

\section{Inclusion Criteria}

The boys had no signs of underlying disease accounting for the short stature. They were identified through a systematic review of growth charts and medical records. They had no signs of chronic or endocrine illness in medical history, clinical examination, and routine laboratory tests and were eligible for recruitment. Calendar age of $9.0-14.5 \mathrm{yr}$ and height at least $2 \mathrm{SD}$ below the mean for age or at least $2 \mathrm{SD}$ below midparental target height. None of the boys had any treatment known to affect growth or bone maturation.

\section{Exclusion criteria}


Chronic illness, a known genetic syndrome, previous treatment with GH, estrogen or androgen. Current treatment with other drugs likely to affect growth including methylphenidate or similar stimulants.

\section{Assessment}

\section{Family history}

A) Maternal pregnancy history, medical illnesses and medication use.

B) Birth weight and length, and estimate of gestational age are important because premature infants with appropriate small weight tend to have a normal growth potential, whereas infants with intrauterine growth retardation who are inappropriately small for gestational age may not have catch-up growth.

C) Complete review of systems:

1- Renal, polyuria and polydipsia for hypothalamic and/or pituitary disorders.

2- Cardiac peripheral edema, murmurs, and cyanosis

3- Gastrointestinal diarrhea, flatulence (malabsorption), vomiting, and/or abdominal pain.

4- Pulmonary sleep apnea, asthma, or symptoms suggestive of cystic fibrosis.

5- Neurological, visual field defects suggesting pituitary neoplasms.

D) Growth history close review of symptoms from growth charts for various disease states.

E) Family history adult height and growth and pubertal patterns of his sibling.

F) Dietary history.

G) Review of the growth chart.

2. Physical Examination: A complete physical examination is the next step in the evaluation and should include:

1- Height and weight.

2- Arm span and upper-to-lower (U/L) body-segment ratio.

\section{Investigations (Lab Evaluation):}

Routine laboratory screening: Includes complete blood count (CBC), sedimentation rate, urine analysis, biochemical profile including serum creatinine and liver enzymes.

\section{Study design:}

The children were classified into two groups:

The first group (20 children) was received Anastrozole tablet (Arimidex®), 1mg daily for one year. 
The second group (20 children) was served as a control group and was received starch tablet daily for one year.

\section{Methods}

The followings were being investigated for the patient:

1. Height measurements were being obtained every one month for 12 months by wall mounted stadimetre, (The Seca 222 wall mounted stadiometre, USA).

2. Laboratory investigations were included:
A. Serum estradiol (E2), (Fishel et al., 1995).
B. Serum testosterone (T), (Chen et al., 1995).
C. Serum follicle stimulating hormone (FSH), (Rebar et al., 1982).
D. Serum leutinizinghormone (LH), (Rebar et al., 1982).
E. Serum insulin-like growth factor type 1 (IGF-1), (Abraham, 1981).

These tests were being done at the beginning of the therapy, and every four months in the two groups for twelve months by the suitable available techniques (ELISA or chemilumine-scence's technique)

\section{Biochemical measurements}

Venous blood samples were withdrawn. Serum concentrations were measured in sera stored at $-20^{\circ} \mathrm{C}$ until required. Serum $\mathrm{T}$ concentrations were determined by Chemiluminescence Immunoassay. The normal values were expected between 2.41 to $8.28 \mathrm{ng} / \mathrm{ml}$ (Chen et al., 1995). Serum estradiol (E2) concentrations were quantified with chemiluminescence enzyme immunoassay with a detection limit of $1.2 \mathrm{pg} / \mathrm{ml}$ (Fishel et al., 1995).

Serum FSH levels were measured by chemiluminescence enzyme immunoassay with a detection limit of 1.4 to $18.1 \mathrm{mIU}($ Rebar et al., 1982). LH levels were measured by chemiluminescence enzyme immunoassay with a detection limit of 0.1 to $6 \mathrm{mIU}$ (Rebar et al., 1982). Serum IGF-I concentrations were determined by Enzyme Linked Immunosorbent assay (ELISA) with a detection limit of $4.9 \mathrm{ng} / \mathrm{ml}$ (Abraham, 1981).

\section{Height measurements}

The growth of the children was followed every month for 12 months after starting the study by wall mounted stadiometre (The Seca 222 wall mounted stadiometre, USA). with sensitivity of $0.1 \mathrm{~cm}$. Children should be measured while they are standing with stadimetre mounted on the wall for stability.

\section{Statistical Analysis}

All values in this work are expressed as mean \pm SEM of the mean (SEM). The results were analyzed by unpaired-t test to determine the differences between two 
means before and after treatment. P-value of $<0.05$ was considered to be statistically significant.

\section{Results}

\section{Serum testosterone levels before and after treatment}

This study showed that the mean level of serum testosterone after therapy with anastrozole (1mg/ day) for four months was significantly higher than that of the placebo group. After continuing the therapy with anastrozole tablets for eight months, the mean level of serum testosterone was found to be significantly higher than those of anastrazole group at four month and placebo group. At 12 month with the same therapy, the mean level of serum testosterone was found to be significantly higher than those of the anastrazole group at four and eight months, and placebo group (Table.1, Fig.1).

Table (1): Serum testosterone (T) levels before and after therapy in anastrozole and placebo groups

\begin{tabular}{|c|c|c|c|c|}
\hline & $\begin{array}{c}\text { Serum T level } \\
\text { before treatment } \\
\mathrm{ng} / \mathrm{mL} \\
\text { Mean }( \pm \mathrm{SE})\end{array}$ & $\begin{array}{c}\text { Serum T level } \\
\text { at } 4 \mathrm{month} \\
\mathrm{ng} / \mathrm{mL} \\
\text { Mean }( \pm \mathrm{SE})\end{array}$ & $\begin{array}{c}\text { Serum T level } \\
\text { at } 8 \mathrm{month} \\
\mathrm{ng} / \mathrm{mL} \\
\text { Mean }( \pm \mathrm{SE})\end{array}$ & $\begin{array}{c}\text { Serum T level at } \\
12 \text { month } \mathrm{ng} / \mathrm{mL} \\
\text { Mean }( \pm \mathrm{SE})\end{array}$ \\
\hline $\begin{array}{c}\text { Placebo group } \\
\mathrm{N}=20\end{array}$ & $0.54 \pm 0.08$ & $0.74 \pm 0.07^{\mathrm{a}}$ & $0.93 \pm 0.07^{\mathrm{a}, \mathrm{b}}$ & $1.1 \pm 0.06^{\mathrm{a}, \mathrm{b}, \mathrm{c}}$ \\
\hline $\begin{array}{c}\text { Anastrazole } \\
\text { group } \\
\mathrm{N}=20\end{array}$ & $1.03 \pm 0.13$ & $2.4 \pm 0.15^{\mathrm{a}}$ & $4.3 \pm 0.21^{\mathrm{a}, \mathrm{b}}$ & $7 \pm 0.21^{\mathrm{a}, \mathrm{b}, \mathrm{c}}$ \\
\hline
\end{tabular}

$\mathrm{a}=$ significantly different from both placebo \& test group at $\mathrm{P} \leq 0.05$

$\mathrm{b}=$ significantly different from Anastrozole treated group value / 4 months

$\mathrm{c}=$ significantly different from Anastrozole treated group value / 8 months 


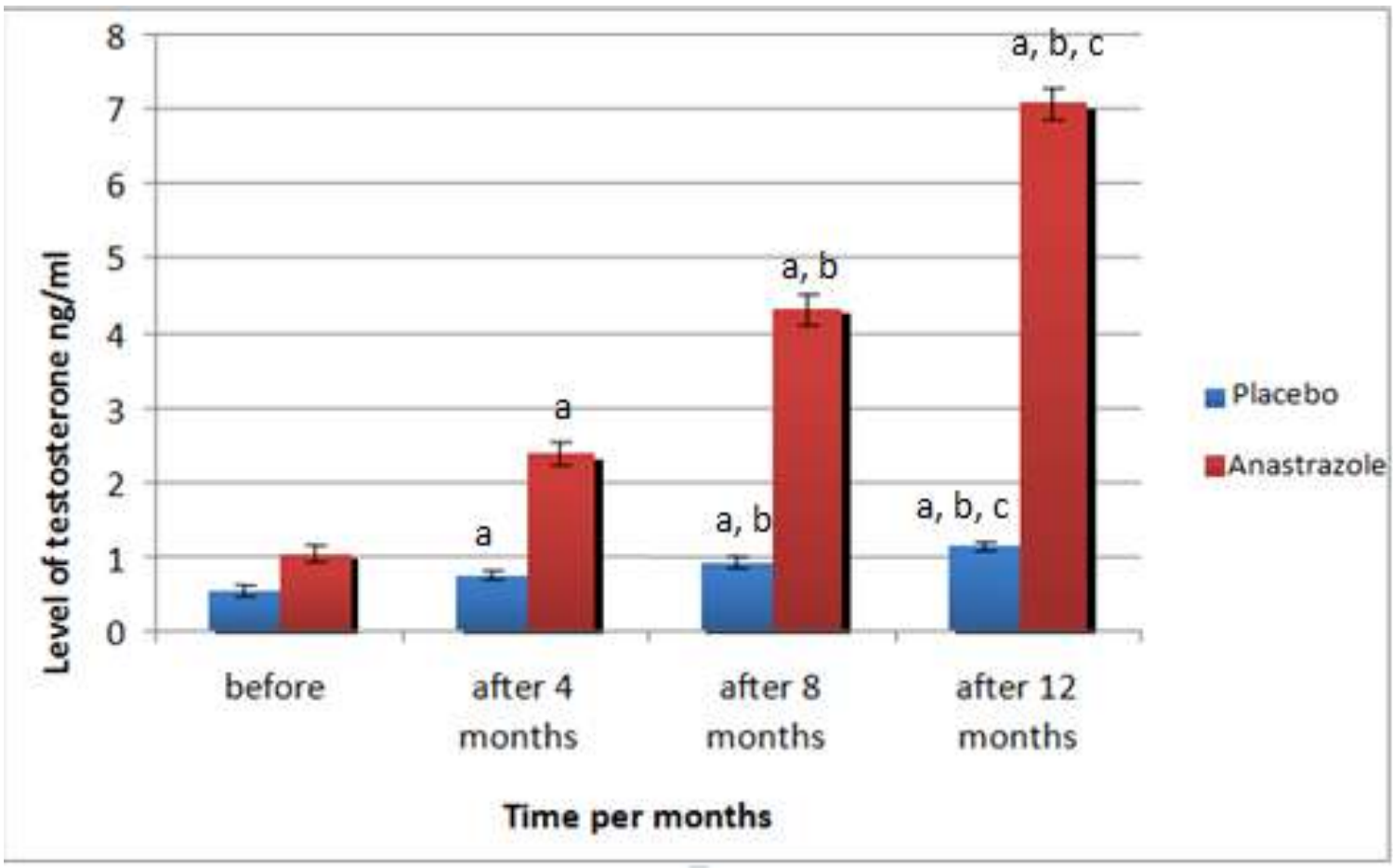

Fig - (1): Serum testosterone levels before and after therapy in anastrozole and placebo groups

Each bar represents the mean of 20 patients with vertical lines indicating SEM

$\mathrm{a}=$ significantly different from both placebo \&test at $\mathrm{P} \leq 0.05$

$\mathrm{b}=$ significantly different from Anastrozole treated group value / 4 months

$\mathrm{c}=$ significantly different from Anastrozole treated group value $/ 8$ months

\section{Serum estradiol levels before and after treatment}

This study showed that the mean level of serum estradiol after treatment with anastrozole for 4 months was significantly lower than those of placebo group. After continuation of therapy to eight months, the mean serum estradiol level was found to be significantly lower than those of the same group at 4 months, or placebo group. At 12 months, the mean level of serum estradiol was continuing significantly lower than those of Anastrazole group at 4 and 8 months or placebo I.S.S groups (Table.2, Fig.2). 
Table (2): Serum estradiol (E2) levels before and after treatment in anastrozole and placebo groups

\begin{tabular}{|c|c|c|c|c|}
\hline & $\begin{array}{c}\text { Serum E2 level } \\
\text { before treatment } \\
\mathrm{pg} / \mathrm{mL} \\
\text { Mean }( \pm \mathrm{SE})\end{array}$ & $\begin{array}{c}\text { Serum } \mathrm{E}_{2} \text { level } \\
\text { at } 4 \text { month } \\
\mathrm{pg} / \mathrm{mL} \\
\text { Mean }(+\mathrm{SE})\end{array}$ & $\begin{array}{c}\text { Serum } \mathrm{E}_{2} \text { level } \\
\text { at } 4 \text { month } \\
\mathrm{pg} / \mathrm{mL} \\
\text { Mean }(+\mathrm{SE})\end{array}$ & $\begin{array}{c}\text { Serum } \mathrm{E}_{2} \text { level } \\
\text { at } 4 \text { month } \\
\mathrm{pg} / \mathrm{mL} \\
\mathrm{Mean}(+\mathrm{SE})\end{array}$ \\
\hline $\begin{array}{c}\text { Placebo group } \\
\mathrm{N}=20\end{array}$ & $70.5 \pm 1.45$ & $72.7 \pm 1.44^{\mathbf{a}}$ & $74.9 \pm 1.46^{\mathbf{a}, \mathbf{b}}$ & $77 \pm 1.48^{\mathbf{a}, \mathbf{b}, \mathbf{c}}$ \\
\hline $\begin{array}{c}\text { Anastrazole } \\
\text { group } \\
\text { N=20 }\end{array}$ & $70 \pm 1.44$ & $65 \pm 1.21^{\mathbf{a}}$ & $59 \pm 0.73^{\mathbf{a}, \mathbf{b}}$ & $54 \pm 0.32^{\mathbf{a}, \mathbf{b}, \mathbf{c}}$ \\
\hline
\end{tabular}

$\mathrm{a}=$ significantly different from both placebo \& test at $\mathrm{P} \leq 0.05$

$\mathrm{b}=$ significantly different from Anastrozole treated group value / 4 months

$\mathrm{c}=$ significantly different from Anastrozole treated group value $/ 8$ months

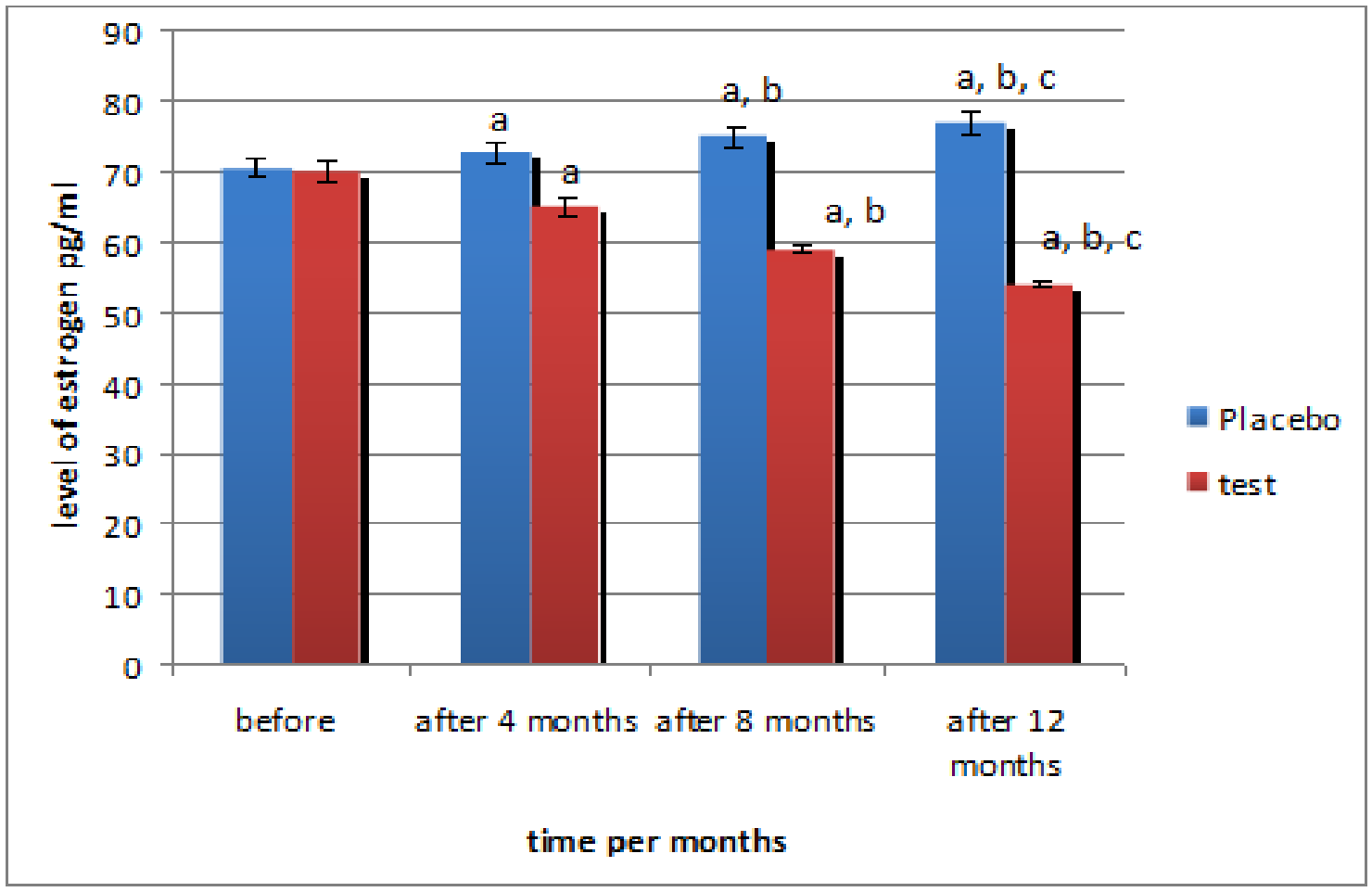

Fig. (2): Serum $E_{2}$ levels before \& after treatment in anastrozole and placebo groups Each bar represents the mean of 20 patients with vertical lines indicating SEM $\mathrm{a}=$ significantly different from both placebo \& test at $\mathrm{P} \leq 0.05$ $\mathrm{b}=$ significantly different from Anastrozole treated group value / 4 months 
$\mathrm{c}=$ significantly different from Anastrozole treated group value $/ 8$ months

3. Serum luteinizing hormone (LH), follicle stimulating hormone (FSH), insulin like growth factor-1(IGF-1) levels before and after treatment

This study revealed that the mean level of serum luteinizing hormone (LH), follicle stimulating hormone (FSH) and insulin like growth factor-1(IGF-1) after treatment with anastrozole (in a dose of $1 \mathrm{mg} /$ day / 4 months, 8 months and 12 months respectively) did not significantly change throughout the duration of the study in Anastrazole or placebo groups (Table.3, Fig.3, Fig.4 and, Fig.5 respectively).

Table (3): Serum luteinizing hormone (LH), follicle stimulating hormone (FSH), insulin like growth factor-1(IGF-1) levels before and after treatment

\begin{tabular}{|c|c|c|c|c|c|c|c|c|}
\hline & \multicolumn{4}{|c|}{$\begin{array}{l}\text { Anastrazole group } \\
\qquad \mathbf{N}=\mathbf{2 0}\end{array}$} & \multicolumn{4}{|c|}{$\begin{array}{l}\text { Placebo group } \\
\qquad \mathbf{N}=\mathbf{2 0}\end{array}$} \\
\hline & $\begin{array}{c}\text { Before } \\
\text { ttt } \\
\text { Mean } \\
( \pm \mathrm{SE})\end{array}$ & $\begin{array}{c}\text { At } 4 \text { mo } \\
\text { Mean } \\
( \pm \text { SE })\end{array}$ & $\begin{array}{c}\text { At } 8 \text { mo } \\
\text { Mean } \\
( \pm \text { SE })\end{array}$ & $\begin{array}{c}\text { At } 12 \\
\text { mo } \\
\text { Mean } \\
( \pm \text { SE })\end{array}$ & $\begin{array}{c}\text { Before } \\
\text { ttt } \\
\text { Mean } \\
( \pm \mathrm{SE})\end{array}$ & $\begin{array}{c}\text { At } 4 \text { mo } \\
\text { Mean } \\
(\underline{+S E})\end{array}$ & $\begin{array}{c}\text { At } 8 \text { mo } \\
\text { Mean } \\
( \pm \text { SE })\end{array}$ & $\begin{array}{c}\text { At } 12 \\
\text { mo } \\
\text { Mean } \\
( \pm \text { SE) }\end{array}$ \\
\hline $\begin{array}{c}\text { LH } \\
(\mathbf{m I U})\end{array}$ & $\begin{array}{c}5.25 \pm 0.0 \\
2\end{array}$ & $\begin{array}{c}5.27 \pm 0.0 \\
2\end{array}$ & $\begin{array}{c}5.32 \pm 0.0 \\
2\end{array}$ & $\begin{array}{c}5.32 \pm 0.0 \\
2\end{array}$ & $\begin{array}{c}5.29 \pm 0.0 \\
4\end{array}$ & $\begin{array}{c}5.30 \pm 0.0 \\
4\end{array}$ & $\begin{array}{c}5.37 \pm 0.0 \\
4\end{array}$ & $\begin{array}{c}5.40 \pm 0.0 \\
4\end{array}$ \\
\hline $\begin{array}{l}\text { FSH } \\
(\mathrm{mIU})\end{array}$ & $\begin{array}{c}0.80 \pm 0.0 \\
4\end{array}$ & $\begin{array}{c}1.01 \pm 0.0 \\
4\end{array}$ & $\begin{array}{c}1.14 \pm 0.0 \\
4\end{array}$ & $\begin{array}{c}1.39 \pm 0.0 \\
2\end{array}$ & $\begin{array}{c}0.79 \pm 0.0 \\
4\end{array}$ & $\begin{array}{c}0.95 \pm 0.0 \\
4\end{array}$ & $\begin{array}{c}1.10 \pm 0.0 \\
3\end{array}$ & $\begin{array}{c}1.36 \pm 0.0 \\
2\end{array}$ \\
\hline $\begin{array}{l}\text { IGF-1 } \\
\mathrm{ng} / \mathrm{mL})\end{array}$ & $\begin{array}{c}4.68 \pm 0.0 \\
3\end{array}$ & $\begin{array}{c}4.71 \pm 0.0 \\
2\end{array}$ & $\begin{array}{c}4.77 \pm 0.0 \\
2\end{array}$ & $\begin{array}{c}4.82 \pm 0.0 \\
1\end{array}$ & $\begin{array}{c}4.70 \pm 0.0 \\
2\end{array}$ & $\begin{array}{c}4.70 \pm 0.0 \\
2\end{array}$ & $\begin{array}{c}4.80 \pm 0.0 \\
1\end{array}$ & $\begin{array}{c}4.80 \pm 0.0 \\
1\end{array}$ \\
\hline
\end{tabular}




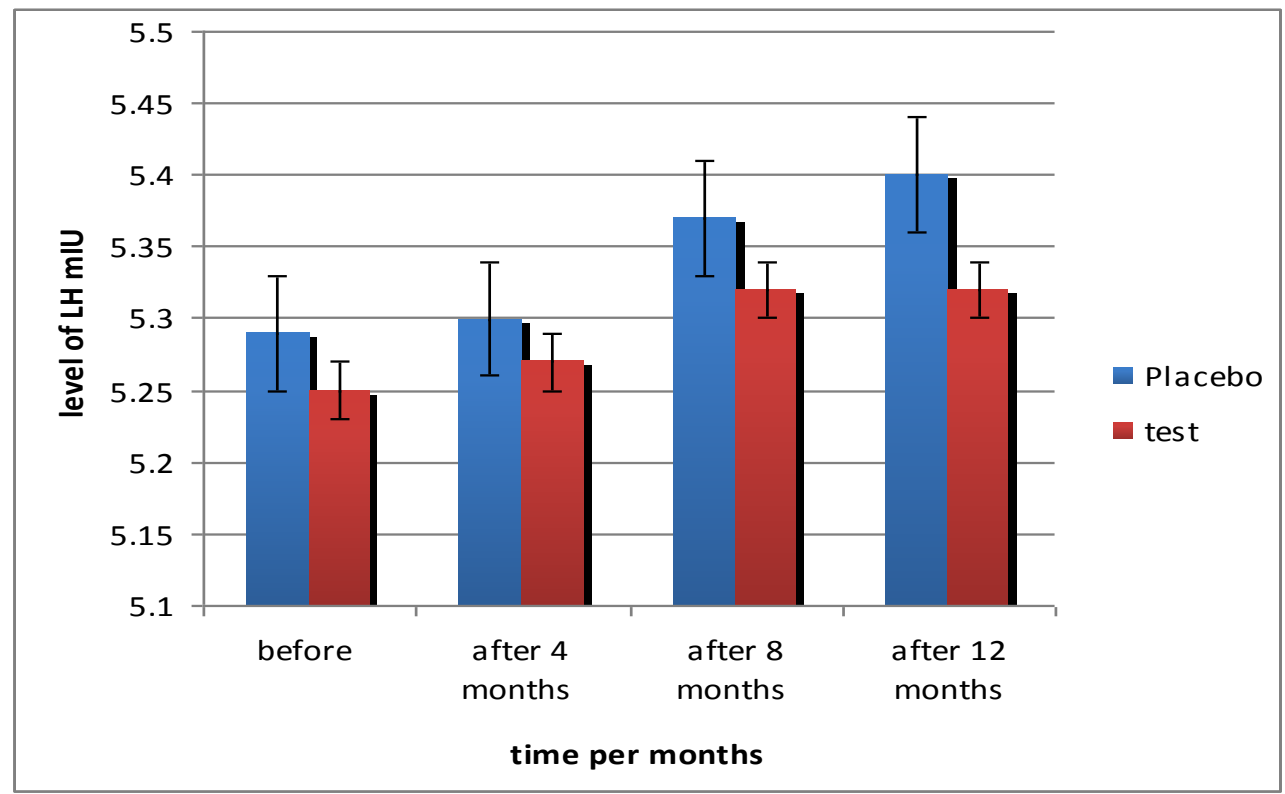

Fig. (3): Serum luteinizing hormone (LH) levels before \& after treatment

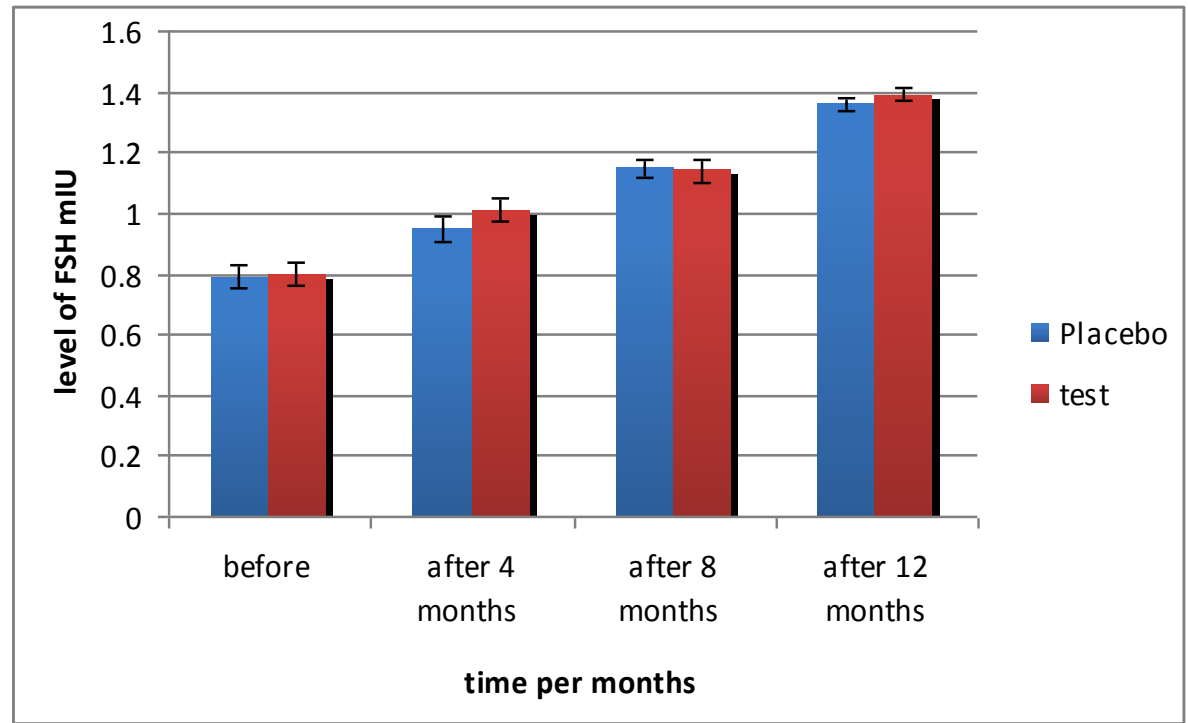

Fig. (4): Serum follicle stimulating hormone (FSH) levels before \& after treatment 


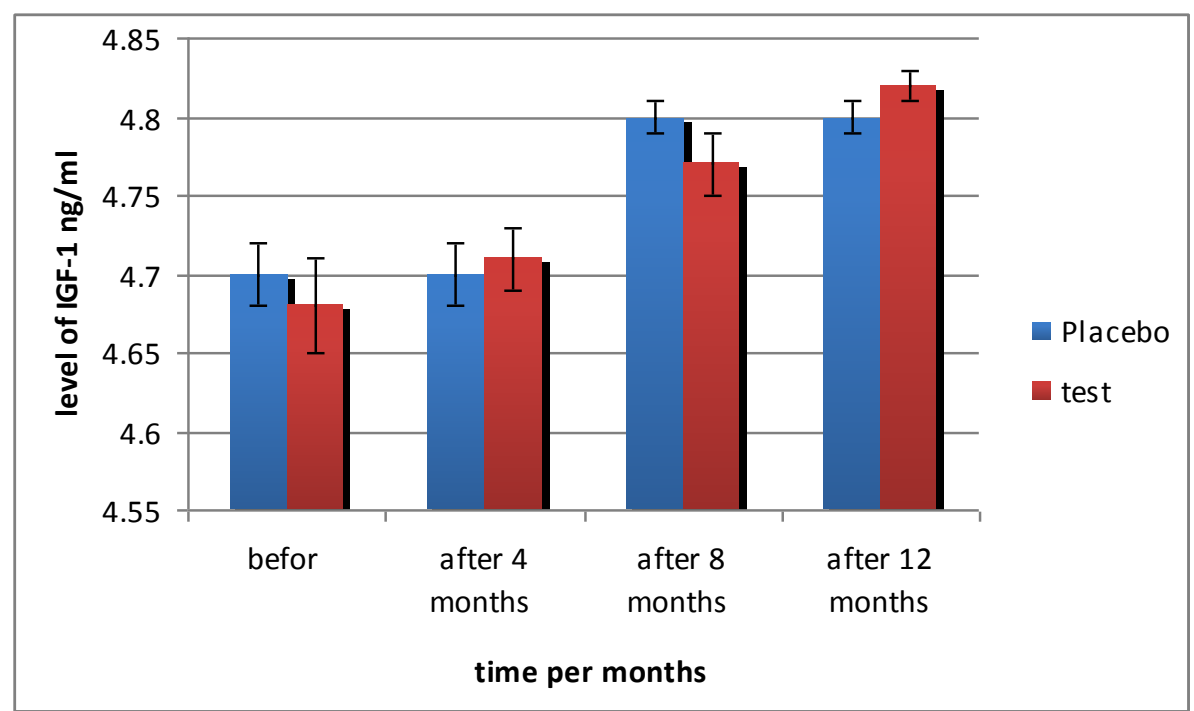

Fig. (5): Serum insulin like growth factor-1(IGF-1) levels before \& after treatment

\section{Height levels before and after treatment}

This study showed that the mean level of height after treatment with anastrozole for 4 months was found to be significantly higher than those of placebo group.

After 8 months of treatment, the mean level of height was found to be significantly higher than those of the treated group with the same drug for 4 months, or placebo groups

By elongation the duration of therapy to 12 months, the mean level of the height was found to be significantly higher than those of the treated group with the same drug for 4 , and 8 months, or placebo groups (Table.4, Fig.6).

Table (4): Height levels before and after treatment

\begin{tabular}{|c|c|c|c|c|}
\hline & $\begin{array}{c}\text { Height level } \\
\text { before treatment } \\
\text { cm } \\
\text { Mean }( \pm \text { SE })\end{array}$ & $\begin{array}{l}\text { Height level } \\
\text { after } 4 \text { months } \\
\qquad \mathrm{cm} \\
\text { Mean (+SE) }\end{array}$ & $\begin{array}{l}\text { Height level } \\
\text { after 8months } \\
\qquad \mathrm{cm} \\
\text { Mean (+SE) }\end{array}$ & $\begin{array}{c}\text { Height level } \\
\text { after 12months } \\
\text { cm } \\
\text { Mean (+SE) }\end{array}$ \\
\hline $\begin{array}{c}\text { Placebo } \\
\mathbf{N}=\mathbf{2 0}\end{array}$ & $148.5 \pm 1.18$ & $148 \pm 1.11^{\mathrm{a}}$ & $149 \pm 1.11^{\mathbf{a}, \mathbf{b}}$ & $149.7 \pm 1.11^{\mathbf{a}, \mathbf{b}}$ \\
\hline $\begin{array}{c}\text { Anastrazole } \\
\qquad \mathbf{N}=\mathbf{2 0}\end{array}$ & $148 \pm 0.96$ & $150 \pm 1.11^{\mathrm{a}}$ & $151.7 \pm 1^{\mathrm{a}, \mathrm{b}}$ & $152.9 \pm 0.98^{\mathrm{a}, \mathrm{b}}$ \\
\hline
\end{tabular}

$\mathrm{a}=$ significantly different from both placebo $\&$ test at $\mathrm{P} \leq 0.05$ 
$\mathrm{b}=$ significantly different from Anastrozole treated group value / 4 months $\mathrm{c}=$ significantly different from Anastrozole treated group value $/ 8$ months

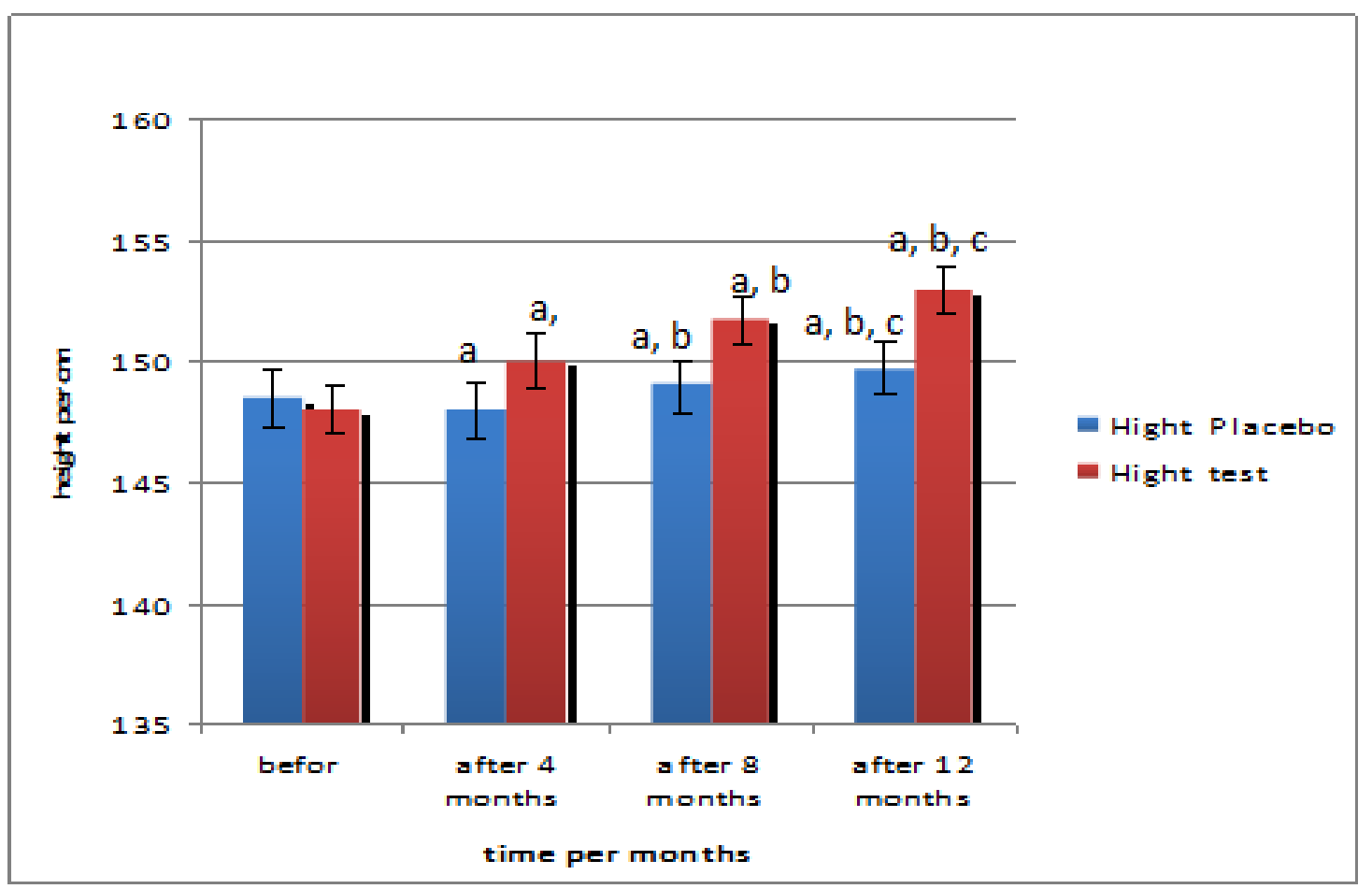

Fig. (6): Height levels before \& after treatment with anastrozole as compared to placebo group

Each bar represents the mean of 20 patients with vertical lines indicating SEM $\mathrm{a}=$ significantly different from both placebo \& test at $\mathrm{P} \leq 0.05$ $\mathrm{b}=$ significantly different from Anastrozole treated group value / 4 months $\mathrm{c}=$ significantly different from Anastrozole treated group value / 8 months 


\section{Discussion}

The approach to boys with growth retardation in puberty stage remains an important clinical challenge. In most children with decreased childhood growth, a specific etiology cannot be identified, a condition termed idiopathic short stature (ISS) ( Wit et al., 1995, Root et al., 1998).

Current strategies for increasing adult height include growth hormone treatment alone or together with Gonadotropin-releasing hormone analog (GnRHa) therapy to suppress pubertal development in boys and girls (Pasquino et al., 2000, Leschek et al., 2004, Wit et al., 2004).

GH doses may increase risk of supraphysiological IGF-I concentration (Mauras et al., 2000). carbohydrate abnormalities (Jorgensen et al., 1988, Walker et al., 1989, Tanaka et al., 1999). and development of acromegalic features (Mauras et al., 2000). Detrimental effects of GnRHa may occur on body composition, muscle strength, and protein, lipid, and calcium metabolism, GnRHa may also inhibit virilization in males (Boot et al., 1998, Palmert et al., 1999, Heger et al., 1999). These effects make the use of $\mathrm{GH}$ and GnRHa unsuitable in the long term if the sole purpose of treatment is to increase final height.

A study by (Yanovski et al., 2003) reported that "treatment with luteinizing hormone-releasing hormone (LHRH) agonist for 3.5 years increased adult height by 0.6 SD in adolescents with very short stature but substantially decreased bone mineral density. Such treatment cannot be routinely recommended to augment height in adolescents with normally timed puberty.

Androgens have direct growth stimulating effects in the growth plate since androgens receptors have indeed been located in human growth plates. In males, testosterone was the principal sex hormone responsible for the pubertal growth spurt, skeletal maturation, accrual of bone mineral, and maintenance of skeleton (Heger et al., 1999).

Estrogen has an important critical role (presumably in both sexes) in gaining and maintaining bone mass, closing of the epiphyses and regulation of gonadotropin through the feedback on gonadotropin secretion. Case reports of patients with estrogen insensitivity (Smith et al., 1994) or estrogen deficiency (Morishima et al., 1995, Carani et al., 1997, Herrmann et al., 2002) have substantiated the fact that in the absence of an estrogen effect on the growth plate, epiphyses remain open, and longitudinal growth continues for an exceptionally long period of time. Because ultimate fusion of the growth plates is estrogen-dependent in both boys and girls, aromatase inhibitors administration may help to slow down epiphysial maturation and allow for greater height potential. On the basis of these observations, it has become possible to postulate that longitudinal growth can be modulated by blocking estrogen biosynthesis with aromatase inhibitors, which inhibit aromatization of C19 androgens [mainly androstenedione and testosterone (T)] to C18 estrogens (Geffner, 2009). 
Aromatase inhibitors may be an attractive alternative for traditional testosterone substitution because these compounds can be administered orally once daily and may result in physiological $24 \mathrm{~h}$ testosterone profiles. Additionally, misuse of aromatase inhibitors is unlikely since testosterone levels will not be stimulated to vastly supraphysiological levels (De Ronde and De Jong, 2011). The clinical features of patients with defects in CYP19A1, the gene encoding aromatase, have revealed a major role for this enzyme in epiphyseal plate closure, which has promoted interest in the use of inhibitors of aromatase to improve adult height (Mauras, 2011).

Third generation aromatase inhibitors are now available and offer significant advantages over weak aromatase inhibitor in terms of potency, safety, and tolerability. Thus, the use of a potent selective aromatase blocker, anastrozole, offers the advantage of continued virilization and maintenance of pubertal body composition in boys while potentially delaying skeletal maturation. Therefore the use of an AI with or without GH is a better option for enhancing the growth potential of short pubertal boys (Feuillan et al., 1993, Leschek et al., 1999, Merke et al., 2000).

Biochemical markers of puberty including serum testosterone, gonadotropins, and changes in the estradiol to-testosterone ratio showed the expected effects of relative estrogen suppression, and the hormone levels eventually remained in the normal range for the pubertal stage (Mauras, 2011).

The current study was conducted to determine whether the aromatase inhibitor anastrozole could play a role on growth and consequently predicted adult height in boys with high estrogen level. Also, the study was aimed to investigate the effects of aromatase inhibition on gonadotropin secretion in boys during prepubertal phase.

Results of the present study showed a significant increase in serum testosterone levels and a significant decline in serum estrogen levels in boys with ISS treated with anastrozole $1 \mathrm{mg}$ taken orally / day for 4, or 8 and 12 months respectively as compared to placebo subjects. These results are consistent with other trials which revealed that estrogen levels were substantially decreased, whereas testosterone levels were significantly increased in those who received anastrozole treatment compared with control subjects (Hero et al., 2006). It was reported that aromatase blockade effectively blocks estrogen production in males with a reciprocal increase in testosterone (Mauras, 2011).

It is well known from experimental evidence and from clinical observations that estradiol has powerful effects on gonadotropin release in men. Modulation of plasma estradiol levels within the male physiological range is associated with strong effects on plasma levels of LH through an effect at the level of the pituitary gland (Pitteloud et al., 2008). Although FSH release is primarily under the control of inhibin, circulating estradiol has a substantial effect on FSH levels in men (Raven et al., 2006).

Aromatase inhibition results in a three-fold increase in levels of FSH in eugonadal men and may potentially stimulate sperm production (Raven et al., 2006, T'sjoen et al., 2005). Due to their mode of action the use of aromatase inhibitors is 
limited to men with at least some residual function of the hypothalamo-pituitarygonadal axis.

Lowering estradiol levels, by administering an aromatase inhibitor, is associated with an increase in levels of $\mathrm{LH}$, follicle-stimulating hormone (FSH) and testosterone (Raven et al., 2006, T'sjoen et al., 2005). These results are in discrepancy with the present study which revealed no significant change in serum luteinizing hormone (LH) and follicle stimulating hormone (FSH) levels that appeared between treatment groups at the beginning of the study. After four, eight, and twelve months of treatment serum levels of LH and FSH in anastrozole group (in a dose of $1 \mathrm{mg}$ / day for twelve months) did not significantly change compared to the placebo group or within the anastrozole group by elongation the duration of therapy (four, eight, and twelve months). These data are in agreement with the concept that the control of gonadotropin secretion before the onset of puberty is mediated via the central nervous system rather than by sex steroids. In accord with the previous findings a study by (Hero et al., 2006).reported no changes in boys who remained prepubertal throughout the study in FSH and LH levels between treatment group of AI and placebo group. Simultaneously, the respective values in the pubertal boys changed significantly in both AI and placebo groups. In the placebopubertal boys, LH and FSH levels gradually increased significantly. On the other hand, in the respective AI group, LH and FSH levels increased more rapidly and remained higher than that in the placebo-treated pubertal boys during the treatment period. (Hero et al., 2006) concluded that the suppression of estrogen biosynthesis by AI decreases the negative feedback control of gonadotropin secretion and raises serum FSH and LH levels after the onset of puberty. This increase in gonadotropin secretion resulted in a supraphysiological rise in T concentrations and rapid testicular growth.

Growth hormone and IGF-1 levels were positively correlated with estradiol levels (Veldhuis et al., 2009). In anastrozole-treated boys in whom treatment started at the beginning of puberty, IGF-I levels were lower than in placebo-treated control (Hero et al., 2009). As expected, GH-deficient boys treated with GH and anastrozole showed a larger increase in height than their GH only-treated control (Mauras et al., 2008). Results of the current study revealed no significant changes in serum IGF-I levels were observed between the different groups before treatment. After 12 months of treatment the serum IGF-1 levels in anastrozole group (1mg oral dose/ day) did not significantly change compared to the placebo group or within the anastrozole group during the therapy (four, eight, and 12 months).

Our explanation of this finding is that the puberty is associated with stimulation of the GH-IGF-I axis, which is normally mediated by estrogen. Estrogen was inhibited in boys treated with anastrozole, as evidenced by no significant change in IGF-I levels in the treatment groups. On contrast to the present results (Hero et al., 2006) reported that serum IGF-I levels were significantly higher in the pubertal placebo-treated boys at 18 and 24 months after the start of treatment compared to AI group. 
The observed growth velocity in the anastrozole group in the current study strongly suggests that in the prepubertal stage, the low estradiol and IGF-I levels and the high androgen levels may be able to enhance growth velocity.

The present study compared the effect of aromatase inhibitor, anastrozole, on predicted adult height (PAH) in boys with ISS. At entry, no significant change in the mean levels of height between treatment groups. After four, eight, and 12 months of treatment, the mean levels of height were significantly increased in anastrozole group compared to placebo group. Also there were a significant increase in the mean levels of height within anastrozole group by elongation the duration of therapy (eight, and 12 months compared to four months).

Clinically, after one year of treatment the mean level of height was improved as much as $(4.9 \mathrm{~cm})$ in anastrozole group which was significantly higher than the increase in the mean level of height in control group $(1.2 \mathrm{~cm})$ after one year of placebo treatment.

In contrast with the previous findings, a study of 12-month treatment with the aromatase inhibitor (anastrozole) in adolescent boys with GH deficiency, failed to find an effect of anastrozole on PAH. This is potentially explained by the short duration of treatment of the study where the patients were pubertal before the start of anastrozle and may be due to GH deficiency (Mauras et al., 2008).

Although the overall results of treatment with AIs are encouraging and their use seems to be rapidly expanding, we agree with the recommendation by several of the studies that endocrinologists should be cautious and that AIs should preferentially be used within carefully controlled clinical trials. More data on adult heights are needed. If AIs are shown to increase adult height, then questions that will still need to be addressed include the optimal agent, dosage, duration of therapy, and whether the intervention is equally efficacious regardless of underlying diagnosis (e.g. do patients with idiopathic short stature, constitutional delay of growth and maturation, and growth hormone deficiency all gain similarly?). What is the average and range of the gain in adult (not predicted adult) height?

In conclusion: Anastrozole treatment in idiopathic short stature boys offers promise and may be a useful choice in the approach to the growth-retarded boys in puberty. Longterm follow-up to final adult height is still needed to fully characterize the safety and efficacy of this approach.

\section{Conflict of interest}

The authors declare that there are no conflicts of interest.

\section{REFERENCES}

Abraham G.E. Ed. (1981): Radioassay Systems in Clinical. Endocrinol. Marcel Dekker, Inc, New York. 
Boot AM, De Muinck Keizer-Schrama S, Pols HA, Krenning EP, Drop SL. (1998):Bone mineral density and body composition before and during treatment with gonadotropin-releasing hormone agonist in children with central precocious and early puberty. J Clin Endocrinol Metab. 83: 370-373.

Carani C, Qin K, Simoni M, Faustini-Fustini M, Serpente S,(1997): Boyd J et al. Effect of testosterone and estradiol in a man with aromatase deficiency. $\mathrm{N}$ Engl J Med.337:91-95.

Chen, A., Bookstein, J.J., Meldrum, D.R.,(1995): Diagnosis of a testosteronesecreting adrenal adenoma by selective venous catheterization. Fertil. Steril,; 55: 1202-1203.

De Ronde W and De Jong Frank H.(2011): Aromatase inhibitors in men: effects and therapeutic options. Reproductive Biology and Endocrinology. 9:93.

Divya Singh, Sabyasachi Sanyal, Naibedya Chattopadhyay.(2011): The role of estrogen in bone growth and formation: changes at puberty. Cell Health and Cytoskeleton, 3:1-12.

Dunkel L. (2006): Use of aromatase inhibitors to increase final height. Mol Cell Endocrinol. 254-255:207-216.

Feuillan PP, Jones J, Cutler Jr GB.(1993): Long-term testolactone therapy for precocious puberty in girls with the McCune-Albright syndrome. J Clin Endocrinol Metab. 77:647-651.

Fishel, S.B., Edwards, R.G., Purdy, J.M., Steptoe, P.C.(1995): Webster, J., Walters, $\mathrm{E}$ et al. Implantation, abortion and birth after in vitro fertilization using the natural menstrual cycle or follicular stimulation with clomiphene citrate and human menopausal gonadotropin, J. In Vitro Fertil. Embryo Transfer, 2: 123131.

Geffner, E.M. (2009): Aromatase Inhibitors to Augment Height: Continued Caution and Study Required. J Clin Res Ped Endo. 1(6):256-261.

Heger S, Partsch CJ, Sippell WG. Long-term outcome after depot gonadotropinreleasing hormone eagonist treatment of central precocious puberty: final height, body proportions, body composition, bone mineral density, and reproductive function. J Clin Endocrinol Metab.1999; 84:4583-4590.

Hero M, Mäkitie O, Kröger H, Nousiainen E, Toiviainen-Salo S, Dunkel L.(2009): Impact of aromatase inhibitor therapy on bone turnover, cortical bone growth and vertebral morphology in pre- and peripubertal boys with idiopathic short stature. Horm Res. 71:290-297.

Hero M, Wickman S, Dunkel L.(2006): Treatment with the aromatase inhibito rletrozole during adolescence increases near-final height in boys with constitutional delay of puberty. Clin Endocrinol (Oxf). 64(5):510-513. 
Herrmann BL, Saller B, Janssen OE, Gocke P, Bockisch A, Sperling H (2002):et al. Impact of estrogen replacement therapy in a male with congenital aromatase deficiency caused by a novel mutation in the CYP19 gene. J Clin Endocrinol Metab. 87:5476-5484.

Hochberg Z, Schechter J, Benderly A, Leiberman E, Rosler A. (1985): Growth and pubertal development in patients with congenital adrenal hyperplasia due to 11-beta-hydroxylase deficiency. Am J Dis Child. 139(8):771-776.

Jorgensen JO, Flyvbjerg A, Lauritzen T, Alberti KG, Orskov H, Christiansen (1988): JS. Dose-response studies with biosynthetic human growth hormone (GH) in GH-deficient patients. J Clin Endocrinol Metab. 67:36-40.

Juul A.(2001) The effects of oestrogens on linear bone growth. Hum Reprod Update.7(3):303-313.

Leschek EW, Jones J, Barnes KM, Hill SC, Cutler Jr GB. (1999):Six-year results of spironolactone and testolactone treatment of familial male-limited precocious puberty with addition of deslorelin after central puberty onset. J Clin Endocrinol Metab. 84:175-178.

Leschek EW, Rose SR,Yanovski (2004): JA, et al. Effect of growth hormone treatment on adult height in peripubertal children with idiopathic short stature: a randomized, double-blind, placebo- controlled trial. J Clin Endocrinol Metab.89(7):3140-3148.

Leung KC, Johannsson G, Leong GM, Ho KK.(2004): Estrogen regulation of growth hormone action. Endocr Rev.25(5):693-721.

Maneatis T, Baptista J, Connelly K, Blethen S.(2000): Growth hormone safety update from the National Cooperative Growth Study. J Pediatr Endocrinol Metab. 13:1035-1044.

Mauras N, Attie KM, Reiter EO, Saenger P, Baptista (2000): J. High dose recombinant human growth hormone $(\mathrm{GH})$ treatment of $\mathrm{GH}$-deficient patients in puberty increases near-final height: a randomized, multicentertrial. J Clin Endocrinol Metab. 85: 3653-3660.

Mauras N, Gonzalez de Pijem L, Hsiang HY, Desrosiers P, Rapaport R, Schwartz ID, Klein KO(2008): et al. Anastrozole increases predicted adult height of short adolescent males treated with growth hormone: arandomized, placebocontrolled, multicenter trial for one to three years. J Clin Endocrinol Metab. 93: 823-831.

Mauras N, O'Brien KO, Oerter Klein K, Hayes V.(2000): Estrogen suppression in males: metabolic effects. J Clin Endocrinol Metab. 85:2370-2377.

Mauras N.(2011): Growth hormone and sex steroids. Interactions in puberty. Endocrinol Metab Clin North Am., 30(3):529-544. 
Merke DP, Keil MF, Jones JV, Fields J, Hill S, Cutler Jr GB.(2000): Flutamide, testolactone, and reduced hydrocortisone dose maintain normal growth velocity and bone maturation despite elevated androgen levels in children with congenital adrenal hyperplasia. J Clin Endocrinol Metab. 85:1114-1120.

Morishima A, Grumbach MM, Simpson ER, Fisher C, Qin K.(1995): Aromatase deficiency in male and female siblings caused by a novel mutation and the physiological role of estrogens. J Clin Endocrinol Metab. 80:3689-3698.

Palmert MR, Mansfield MJ, Crowley WF Jr, Crigler JF Jr, Crawford JD, Boepple (1999): PA. Is obesity an outcome of gonadotropin-releasing hormone agonist administration? Analysis of growth and body composition in 110 patients with central precocious puberty. J Clin Endocrinol Metab. 8 4:4480-4488.

Pasquino AM, Pucarelli I, Roggini M, Segni M.(2000): Adult height in short normal girls treated with gonadotropin-releasing hormone analogs and growth hormone. J Clin Endocrinol Metab. 85(2): 619-622.

Pitteloud N, Dwyer AA, DeCruz S, Lee H, Boepple PA, Crowley WF(2008): Jr et al. Inhibition of luteinizing hormone secretion by testosterone in men requires aromatization for its pituitary but not its hypothalamic effects: evidence from the tandem study of normal and gonadotropin releasing hormone-deficient men. J Clin Endocrinol Metab, 93:784-791.

Raven G, de Jong FH, Kaufman JM,(2006): de Ronde W: In men, peripheral estradiol levels directly reflect the action of estrogens at the hypothalamopituitary level to inhibit gonadotropin secretion. J Clin Endocrinol Metab, 91: 3324-3328.

Rebar RW, Erickson GF, Yen SSC.(1982): Idiopathic premature ovarian failure: clinical and endocrine characteristics. Fertil Steril 1982; 37:35-41

Root AW, Kemp SF, Rundle AC, Dana K, Attie KM.(1998): Effect of long-term recombinant growth hormone therapy in children. the National Cooperative Growth Study, USA, 1985-1994. J Pediatr Endocrinol Metab. 11:403-412.

Root AW, Kemp SF, Rundle AC, Dana K, Attie KM.(1998): Effect of long-term recombinant growth hormone therapy in children-the National Cooperative Growth Study, USA, 1985-1994. J Pediatr Endocrinol Metab. 11:403-412.

Smith EP, Boyd J, Frank GR, Takahashi H, Cohen RM, Specker B (1994): et al. Estrogen resistance caused by a mutation in the estrogen-receptor gene in a man. N Engl J Med. 331:1056-1061.

Stevens DA, Williams GR.(1999): Hormone regulation of chondrocyte differentiation and endochondral bone formation. Mol Cell Endocrinol. 151:195-204. 
T'sjoen GG, Giagulli VA, Delva H, Crabbe P, De Bacquer D, Kaufman JM. (2005):Comparative assessment in young and elderly men of the gonadotropin response to aromatase inhibition. J Clin Endocrinol Metab, 90:5717-5722.

Tanaka T, Seino Y, Fujieda K, Igarashi Y, Yokoya S, Tachibana K (1999): et al. Pharmacokinetics and metabolic effects of high-dose growth hormone administration in healthy adult men. Endocr J. 46:605-612.

The Seca 222 wall mounted stadiometer, USA.

Vanderschueren D, Vandenput L, Boonen S, Lindberg MK, Bouillon R, Ohlsson C. Androgens and bone (2004):. Endocr Rev.; 25(3):389-425.

Veldhuis JD, Mielke KL, Cosma M, Soares-Welch C, Paulo R, Miles JM(2009): et al. Aromatase and 5 alpha-reductase inhibition during an exogenous testosterone clamp unveils selective sex steroid modulation of somatostatin and growth hormone secretagogue actions in healthy older men. J Clin Endocrinol Metab, 94:973-981.

Walker J, Chaussain JL, Bougneres PF. (1989):Growth hormone treatment of children with short stature increases insulin secretion but does not impair glucose disposal. J Clin Endocrinol Metab. 69:253-258.

Wilton P (1999): Adverse events during GH treatment: 10years' experience in KIGS, a pharmaco epidemiological survey. In: Ranke MB, Wilton P, eds. Growth hormone therapy in KIGS-10 years' experience. Heidelberg: Johann Ambrosius Barth Verlag; 349-364.

Wiren K, Keenan E, Zhang X, Ramsey B, Orwoll E. (1999):Homologous androgen receptor up-regulation in osteoblastic cells may be associated with enhanced functional androgen responsiveness. Endocrinology. 140:3114-3124.

Wit JM, Balen HV, Kamp GA, Oostdijk W. Benefit (2004): of postponing normal puberty for improving final height. Eur J Endocrinol.;151(suppl 1):S41-S45.

Wit JM, Boersma B, de Muinck Keizer-Schrama SM, Nienhuis HE, Oostdijk W, Otten BJ(1995): et al. Long-term results of growth hormone therapy in children with short stature, subnormal growth rate and normal growth hormone response to secretagogues. Clin Endocrinol (Oxf). 42:365-372.

Wit JM, Boersma B, de Muinck Keizer-Schrama SM, Nienhuis HE, Oostdijk W, Otten BJ.(1995): Long-term results of growth hormone therapy in children with short stature, subnormal growth rate and normal growth hormone response to secretagogues. Clin Endocrinol (Oxf). 42:365-372.

Wit JM, Hero M, Nunez SB.(2011): Aromatase inhibitors in pediatrics. Nat Rev Endocrinol. 25; 8(3):135-147. 
Yanovski JA, Rose SR, Municchi G(2003): et al. Treatment with a luteinizing hormone-releasing hormone agonist in adolescents with short stature. N Engl J Med. 348:908-917.

$$
\text { الملخص العربى }
$$

تأثير العلاج المثبط لإنزيم الأروماتيز على طول البالغين المتوقع فى الأولاد قبل البلوغ مع قصر

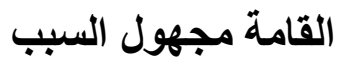

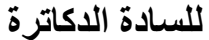

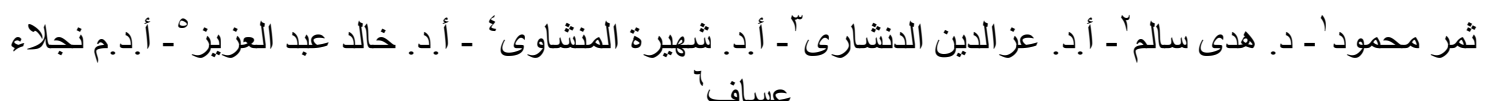

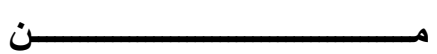

ا ـ قسم الصيدلة الإكلينيكيةـ كلية الصيدلة ـ جامعة مصر للعلوم و التكنولوجيا

r- قسم الصيدلة الإكلينيكية- كلية الصيدلة- جامعة الأز هربنات

بـ - قسم الأقربازين و السموم- كلية الصيدلةـ جامعة القاهرة

ع ـ قسم الصيدلانيات و الصيدلة الصناعيةـ كلية الصيدلة - جامعة بنى سويف

ــ قسم المسالك البولية ـ كلية الطب - جامعة طنطا

7ـ قسم الأقربازين و السمومـ كلية الصيدلة- جامعة مصر للعلوم و التكنولوجيا

يعتبر دواء الأنستر ازول مثبط قوى لإنزيم الأروماتيز وقد استهدفت الدر اسـة إلى الكثف عن عن تأثنير تقييد

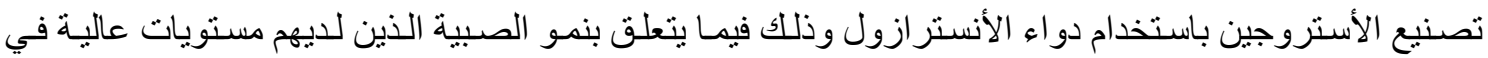

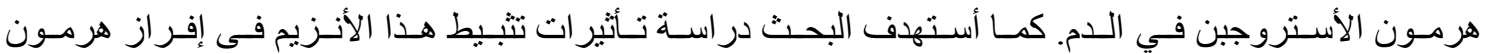

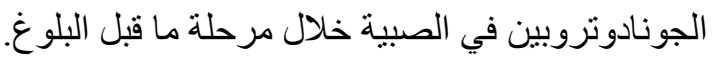

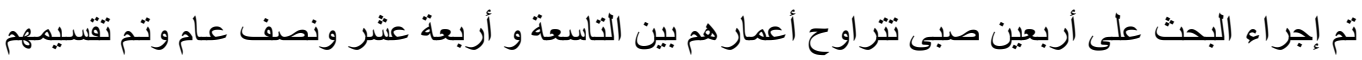

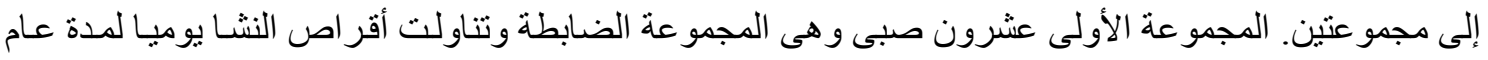

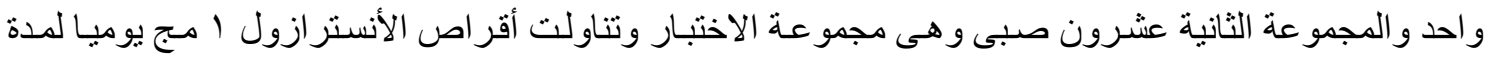

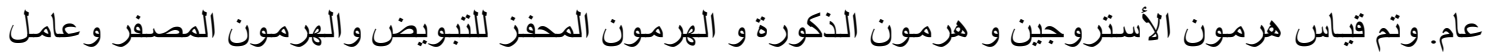

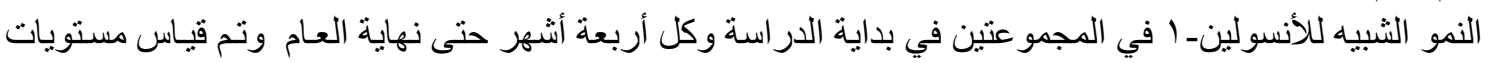
الطول فى الصبية في بداية الدراسة ثم شهريا حتى نهاية الدراسة.

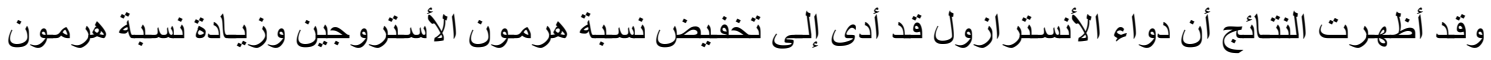

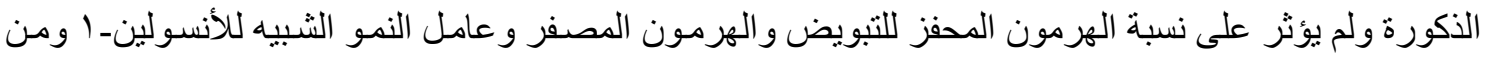

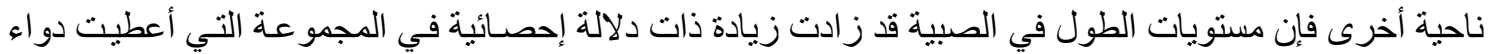

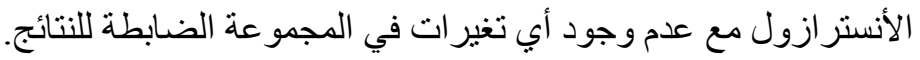

